\title{
ANALYSIS OF LIVER RECIPIENTS SURVIVAL WITH DONOR RISK INDEX (DRI): A PROSPECTIVE STUDY OF CADAVERIC DONORS FROM OPO-HC-UNICAMP AND THEIR RECEPTORS
}

\author{
Análise da sobrevivência de receptor de fígado com índice de Risco de Doador (IRD): \\ Estudo prospectivo de doadores falecidos da OPO-HC-UNICAMP e seus receptores
}

Patricia Kajikawa1', Ilka de Fatima Santana Ferreira Boin², Helbert Oliveira Manduca Palmiero', Helder Zambelli

\begin{abstract}
Introduction: In 2006, a donor risk index (DRI) was published based on data such as age, race, height, cause of brain death, cardio respiratory arrest, split-organ and ischemia time. Purpose: To study the survival rate of liver recipient with DRI. Method: This is an analytic and prospective study. The characteristics from the liver donor were: age (years), race (white/ black/Asian), height $(\mathrm{cm})$, cause of brain death (anoxia, trauma, stroke or tumor), presence of cardiac arrest, cold ischemia time and procurement place (local, regional or national). The liver recipients' characteristics were: age (years), etiology of liver disease, MELD score (total bilirubin, creatinine and IRN), warm ischemia time (minutes), ICU time (days), pretransplant renal injury (yes/no) and Child-Pugh classification. From April 2008 to May 2009 all consecutive 66 OLTs and their respective DRI were analyzed. Recipients were followed up for at least six months in order to evaluate statistically the association between recipient survival and DRI at our service. The Kaplan-Meier method was used to analyze survival rate (using the log-rank test) and the Cox regression test to identify predictive factors. Results: There was statistical difference in the cumulative proportion of survival according to the $1.7>\mathrm{DRI}>1.7$ levels $(\mathrm{P}=0.03)$. Recipients with MELD $>24$ had shorter survival rate $(40 \%)$ than MELD $\leq 24$ recipients $(80 \% ; \mathrm{P}=0.03)$ and the Cox regression test for survival time showed that patients with higher risk of death were: recipients with high values of MELD score and donor age with risk of death of $8 \%$ over 50 years; and DRI with 2\% risk of death for each extra point. Conclusion: There was association between donor risk index and recipient survival. High MELD score values, DRI and donor age are variables that are found associated with the highest number of deaths and shorter survival.
\end{abstract}

Keywords: Liver Transplant, Donor Selection, Survival.

\section{INTRODUCTION}

Instituição:

${ }^{1}$ Faculty of Medical Sciences, Unicamp - Campinas/SP - Brazil

${ }^{2}$ Unit of Liver Transplantation, Unicamp - Campinas/SP - Brazil

${ }^{3} \mathrm{OPO}$ - Unicamp - Campinas/SP - Brazil

Correspondência:

Ilka Boin

Rua Aldo Oliveira Barbosa, 184 - CEP 13086-030 - Campinas/SP Brazil

Tel.: 551932891577

E-mail: ilkaboin@yahoo.com

From the 1980s, transplantation has become a legitimized solution therapy for end-stage liver diseases. As an alternative strategy to increase the amount of organ donors, transplant teams increasingly consider and assess the use of marginal, non-ideal donors, or with expanded criteria. ${ }^{1}$ Feng et al 2006, ${ }^{2}$ conducted a quantitative assessment of donor characteristics by forming a Donor Risk Index (DRI) according to the characteristics of the donor and the graft. The estimate DRI was based on data such as age, race, height, cause of brain death, occurrence of cardiac arrest, use of split-liver, cold ischemia time and origin of the organs (local, regional and national). The score which allows the analysis of the feasibility of transplantation is not subjective according to the criteria for each team, but it is an objective and standardized analysis, minimizing 
both the mortality and morbidity of recipients. ${ }^{3}$ Survival after transplantation is studied and associated with multiple factors, such as donor characteristics, conditions of graft transplantation techniques, characteristics of the receiver and their MELD, ${ }^{4-6}$ in order to decrease waiting list time mortality without reducing the survival in short and long-term recipients. The inclusion of the so-called marginal donors, the recent creation of a donor risk index (DRI) and an important discussion that exists in the global scientific literature on the possible factors associated with survival of the recipient led us to study the survival of hepatic transplant patients according to the characteristics of donors and recipients from a prospective analysis.

\section{METHODS}

This is a prospective study with data collected from the Organ Procurement Organization (OPO) and Unit of Liver Transplantation - Unicamp (State University of Campinas) from April 2008 to May 2009. The recipients had their preoperative data collected and followed up for at least six months in order to analyze the post-operative clinical assessment and short-term survival. The MELD calculation was performed by the formula: 3.8 logn seric bilirubin $(\mathrm{mg} /$ $\mathrm{dL})+11.2 \log \mathrm{RNI}+9.6 \operatorname{logn}$ seric creatinine $(\mathrm{mg} / \mathrm{dL})$ +6.4 , considering that the minimum values of creatinine and RNI corresponded to 1.0 , and the maximum value of creatinine corresponded to $4 \mathrm{mg} / \mathrm{dL}{ }^{3}$

The donor variables required for the DRI, as proposed by Feng et al2 were collected. The variables of the recipients were collected: age (years), gender (male/female), race (white, black, or other), hepatic disease, presence of hepatitis C - HCV (yes or no), MELD (model for end-stage liver disease) score, preoperative serum sodium (mEq/l), surgery date, date of last visit or death, intensive care unit (ICU) time in days, use of split-liver graft, ChildPugh-Turcotte classification (CTP), pre-transplant renal injury (yes/no) and warm ischemia time (minutes). DRI was analyzed in steps: $1-1.2 ; 1.21-1.4 ; 1.41-1.6 ; 1.61-1.8$ and over 1.81 and $1.7>$ DRI $>1.7(3,6)$. The Kaplan-Meier method was used to analyze the survival rate and the Cox regression test was used to identify the predictive factor.

\section{RESULTS}

DIn the studied period, 66 or thotopic liver transplantations (OLTs) were performed with average DRI being 1.45 (75\% had $<1.7$ and $25 \%>1.7)$. Recipients with DRI $>1.7$ had shorter survival (78\%) than those with DRI $<1.7$ (88 \%; P $=0.03)$. Recipients with MELD $>24$ had shorter survival (43\%) than those with MELD $\leq 24$ (Figure 1 and 2).
The Cox regression test for survival time showed higher risk of death when the recipients had high MELD score values (beta $=0.155 ; \mathrm{HR}=1.08 ; \mathrm{P}=0.001$ ), donor age over 50 (beta $=0.155 ; \mathrm{HR}=8 \% ; \mathrm{P}=0.02$ ) and $\mathrm{DRI}>1.5$ (beta=0.76; $\mathrm{HR}=1.02 ; \mathrm{P}=0.02$ ).

\section{Figure 1 - Kaplan-Meier survival rate showed that DRI $>1.7$ recipients have shorter survival rate (78\%) than those with DRI $<1.7$ ( $88 \% ; P=0.03$ by the log-rank test).}

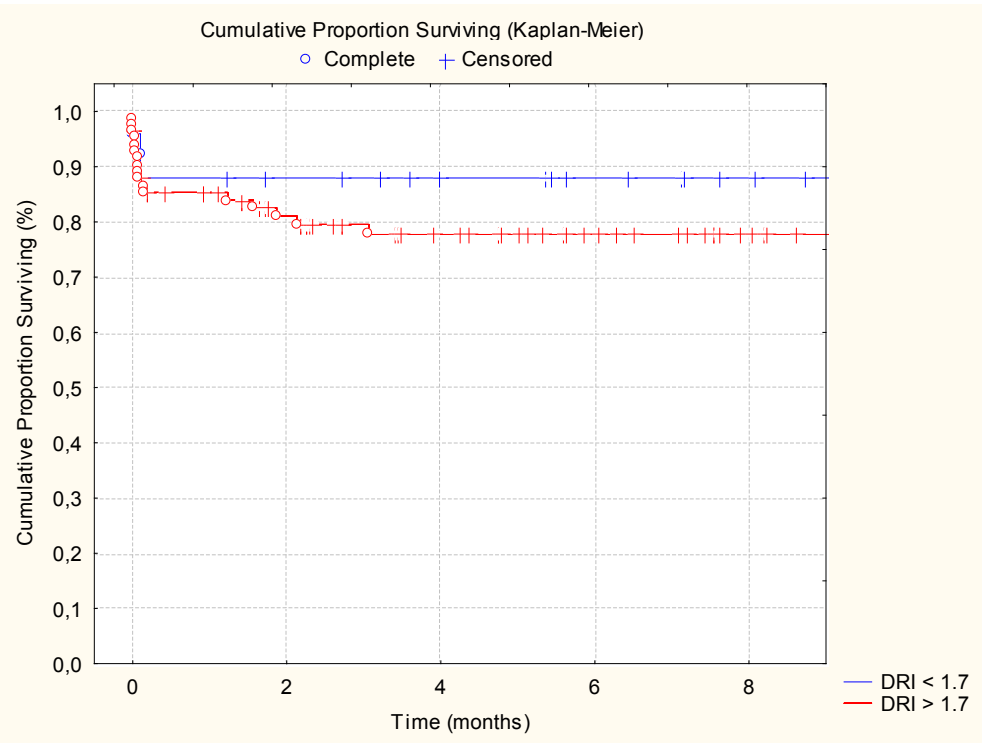

Figure 2 - MELD $>24$ recipients have shorter survival rate (43\%) than those with MELD $\leq 24$ (77\%; $P=0.03$ by the log-rank test).

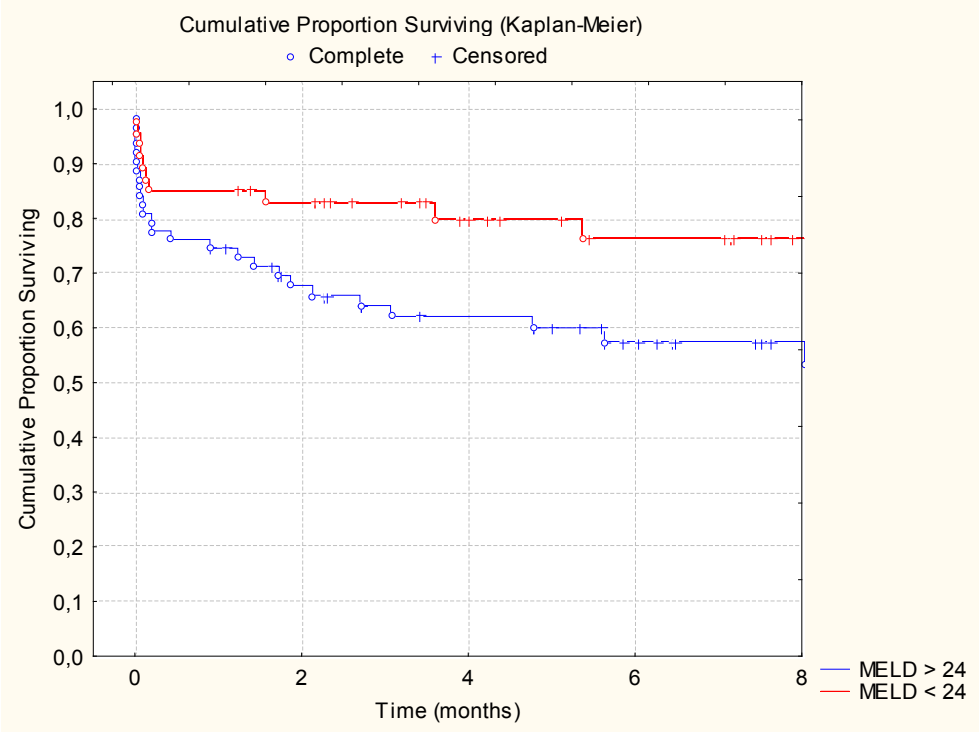




\section{DISCUSSION}

As an alternative strategy to increase the number of organ donors, transplant teams increasingly consider and assess the use of donors known as marginal, non-ideal, or with expanded criteria. ${ }^{1-3}$ Organ allocation based on Model for End-Stage Liver Disease (MELD) resulted in a decrease in the waiting list mortality in the United States. However, reports suggest an increase in the resource utilization as consequence.

Primary dysfunction (PDF) after liver transplantation can be associated with several factors. In our study a strong correlation was not found between PDF and DRI. The same was observed by Avolio et al ${ }^{3}$ who related the incidence of graft PDF to the donor age, ultrasound signs of steatosis, AST donor (aspartate amino transferase), cell saver infusion, and warm and cold ischemia times.

Foxton et al. using multivariate analysis showed that patients who had MELD $>24$, refractory ascitis, alcoholic disease and Budd-Chiari syndrome had prolonged ICU stay. Upon the analysis of the use of higher DRI and longer ICU stay, need for renal replacement therapy, increased cost, or hospital survival on univariate analyses, no difference was found. ${ }^{4}$

In our study, DRI over 1.7 was associated with poor survival as well as those patients with above 24 MELD. Our option to divide into two classes has been described before. ${ }^{6}$ The same was published by Avolio et al 3 who stratified donors into two classes according to the DRI (low risk, DRI $<1.7$, and high risk, DRI $>$ or $=1.7$ ) and they proposed a new index, namely the organ patient index (OPI) which was calculated adding the Model for End-stage Liver Disease
(MELD) score to the DRI. Those cases with low DRI showed better survival rate than those with high DRI, but the OPI could better predict outcomes than DRI, increasing the gap in the long-term graft survival between low- and high-risk classes.

Bonney et al ${ }^{5}$ showed that MELD at transplant was the only significant predictor to the patient survival. MELD at transplant and above 1.7 DRI were associated with a poorer graft survival $(\mathrm{P}=0.03)$. There was a trend toward a poorer graft survival in high DRI grafts transplanted in low and "intermediate" MELD categories $(\mathrm{P}=0.47$ and 0.006 , respectively). However, in the high MELD category, there was a similar graft survival for both high and low DRI grafts. In conclusion, they have shown that patients with low and intermediate MELDs at transplantation may be better served by a low DRI graft, whereas patients with high MELD may not be harmed by receiving a high DRI graft.

For further research, it is very important to carry out by associating several donor and recipient factors in order to attain a new score that can predict primary dysfunction or survival rate after liver transplantation and improve the best organ allocation for the best recipient.

\section{CONCLUSION}

There was a correlation between the donor risk index and recipient survival. High MELD score values, DRI and donor age are variables which are found linked to the highest amount of deaths and shorter survival. The future aim is to allocate organs taking into account the association of MELD score and DRI.

\section{RESUMO}

Introdução: Em 2006, foi publicado um índice de risco de doador (IRD) baseado em dados como idade, raça, altura, causa da morte encefálica, parada cardiorrespiratória, divisão de órgãos e tempo de isquemia. Objetivo: Estudar a taxa de sobrevivência de receptor de fígado com IRD. Método: Estudo analítico e prospectivo. As características do doador do fígado foram: idade (anos), raça (branca/negra/asiática), altura (cm), causa da morte encefálica (anóxia, trauma, derrame ou tumor), presença de parada cardíaca, tempo de isquemia fria e local da procura (local, regional ou nacional). As características dos receptores do fígado foram: idade (anos), etiologia da doença hepática, contagem MELD (bilirrubina total, creatinina e IRN), tempo de isquemia quente (minutos), tempo de UTI (dias), lesão renal pré-transplante (sim/não) e classificação Child-Pugh. De abril de 2008 a maio de 2009, 66 TOF consecutivos e seus respectivos IRD foram analisados. Os recipientes foram seguidos por pelo menos seis meses para avaliar estatisticamente a associação entre sobrevivência do receptor e o IRD em nosso serviço. Foi utilizado o método Kaplan-Meier para analisar a taxa de sobrevivência (usando teste log-rank) e o teste de regressão de Cox para identificar fatores preditivos. Resultados: Houve diferença estatística na proporção cumulativa de sobrevivência de acordo com os níveis $1.7>\mathrm{DRI}>1.7$ ( $\mathrm{P}=0.03)$. Receptores com MELD>24 tiveram menor taxa de sobrevivência (40\%) do que receptores com MELD $\leq 24(80 \%$; $\mathrm{P}=0.03)$ e o teste de regressão de Cox para tempo de sobrevivência mostrou que pacientes com maior risco de morte foram: receptores com altos valores de MELD e idade do doador com risco de morte de $8 \%$ acima de 50 anos e IRD com risco de morte de $2 \%$ para cada ponto extra. Conclusão: Houve associação entre índice de risco de doador e sobrevivência de receptor. Valores altos de MELD, IRD e idade do doador são variáveis encontradas associadas ao número mais alto de mortes e menor sobrevivência.

Descritores: Transplante Hepático; Seleção do Doador; Sobrevivência.

JBT J Bras Transpl. 2013;16(4):1799-1823 


\section{REFERÊNCIAS}

1. Feng S, Goodrich NP, Bragg-Gresham JL, Dykstra DM, Punch JD, DebRoy MA, Greenstein SM, Merion RM. Characteristics associated with liver graft failure: the concept of a donor risk index. Am J Transplant. 20066:783-90.

2. Rocha MB, Boin IFSF, Escanhoela CAF, Leonardi LS. Can the use of marginal liver donors change recipient survival rate? Transplant Proc. 2004; 36:914-5.

3. Foxton MR, Al-Freah MA, Portal AJ et al. Increased model for endstage liver disease score at the time of liver transplant results in prolonged hospitalization and overall intensive care unit costs. Liver Transpl 2010;16(5):668-77.
4. Bonney GK, Aldersley MA, Asthana S, et al. Donor risk index and MELD interactions in predicting long-term graft survival: a singlecentre experience. Transplantation 2009;87(12):1858-3.

5. Boin Ide F, Leonardi MI, Udo EY et al. The application of MELD score in patients submitted to liver transplantation: a retrospective analysis of survival and the predictive factors in the short and long term. Arq Gastroenterol 2008;45(4):275-83.

6. Avolio AW, Siciliano M, Barbarino R et al. Donor risk index and organ patient index as predictors of graft survival after liver transplantation. Transplant Proc 2008; 40(6):1899-902. 